\title{
A Study on Peoples' Perceptions towards Online Shopping
}

\author{
K.S. Silpa, P.U. Rajasree and Dr.P. Balasubramanian
}

\begin{abstract}
Online shopping is a form of Electronic commerce allowing consumers to directly buy goods or services from a seller over the internet without an intermediary. Modern customers have an urge towards e-shopping as they are techno savvy and always look for choices prior to the final decision. In coming years, great online revolution is expected in India since there is a huge population who surf the internet. This paper aims to study peoples' perception towards online shopping. Dates' are collected using convenience random sampling method with 100 respondents. As a result of data analysis it is found that majority of respondents' alleged that online shopping is better than traditional shopping and agrees to the point that online shopping will be more in near future.
\end{abstract}

Keywords--- Electronic Business or E-business, Electronic Commerce, E-Marketing, Online Shopping, Perception.

\section{INTRODUCTION}

$\mathrm{I}_{\mathrm{e}}^{\mathrm{N}}$ $\mathrm{N}$ the era of globalization along with the expansion of e-commerce, various businesses started their sales and marketing efforts for their products through internet. Over the decades, organizations are providing soup to nut to their customers through online. Online shopping is one of the fastest growing phenomenons. It is considered as medium for transaction between firms and consumers. Online shopping also includes supply chain management, marketing over internet, $24 \times 7$ timing, availability of variety of products etc.

Electronic commerce draws on technologies such as mobile commerce, supply chain management, online transaction processing, electronic data interchange, inventory management system, electronic fund transfer etc. E-commerce may take up some of the subsequent facilities such as B2B electronic data inter change, provide direct retail sale and marketing to customer, employ in launching of new products and services etc.

Online shopping is a form of electronic commerce which allow consumer to buy products and services over internet. Through online shopping many organizations have gained remarkable opportunity to boost their sales and to uphold

K.S. Silpa, Student, Department of Commerce and Management, Amrita School of Arts and Sciences, Amrita Vishwa Vidyapeetham University.

P.U. Rajasree, Student, Department of Commerce and Management, Amrita School of Arts and Sciences, Amrita Vishwa Vidyapeetham University.

Dr.P. Balasubramanian, Assistant Professor in Finance, Department of Commerce and Management, Amrita School of Arts and Sciences, Amrita Vishwa Vidyapeetham University.

DOI: 10.9756/BIJIEMS.8187 direct relationship with their customers. The new businesses provide all kind of products at the doorway of the e-shoppers in the finger tip. The business model for admirable services quality is based on various fundamentals such as low price, big range of choices, ample information about products, availability and convenience.

Revolutionary change in the development of online shopping is due to varying lifestyle of the consumers in and expansion of online activity. Major e-shoppers grab online opportunities since different products get better discounts. Much above that, it saves time and gives total relief from the crowd.

Everything has merits and demerits. Approach of Indians is more tending towards real shopping where they can actually touch, and compare products before buying. Therefore Indian society faces difference in peoples' opinion towards online shopping. This paper attempts to study on peoples' perception towards online shopping and also tries to extrapolate information regarding the demand for the same.

\section{LITERATURE REVIEW}

As per the project ten articles were reviewed and summaries of the same are listed below:

- $\quad(2013)^{1}$ Adrita Goswami, Pallavi Baruah and Sarat Borah in their research paper titled "customer satisfaction towards online shopping with special reference to teenage group of Jorhat town" stated that vast number of teenage groups is highly attracted towards online shopping due to the availability of enormous convenience. They also suggest that online marketers should have a deep concern on the customer's satisfaction to retain the customers.

- $(2014)^{2}$ e-Commerce survey held in $26^{\text {th }}$ April, revealed that an additional $35 \%$ of online shopping sites have increased than last year. This survey was organized by Alexa (an Amazon owned company). It also shows the enormous space available in e-Commerce sector.

- $\quad(2015)^{3}$ Money Today (magazine) produced an article which describes about the risks involved in online shopping and various suggestions to overcome it. The risks associated with the e-Shopping are lack of tangibility, dubious websites, refund blues and faulty delivery. The suggestions are buying from trusted websites, check the websites privacy policy, refund policy, use cash on delivery option and many others. 
- $(2014)^{4}$ Prashant Singh, in his study based on "customers' buying behavior towards online shopping", analyzed that e-Buyers are interested in apparels like women, men, and kids clothing , watches, home and kitchen appliances etc . On the other hand, they dislike products like perfumes, footwear etc.

- $(2010)^{5}$ Vaggelis Saprikis, Admantia Chouliara and Muro Viachopoulou in their study headed "Perception towards online shopping: Analyzing the Greek university", where the expectation of adopters and non-adopters are significantly differentiated. Privacy policy and online shop[ping risk are issues which were pointed upon.

- $\quad(2013)^{6}$ Rashed Al Karim, in his article from the IOSR journal of Business and management with the title "customer satisfaction in online shopping: A study into the reasons for motivations and inhibitions," describes that nearly $90 \%$ of respondents use internet daily but most of them do not use it to buy products.

- $(2008)^{7}$ ukessays.com published an articles titled "Changing attitudes of Indian consumer towards online shopping" which enumerate that companies are trying to convert potential buyers into active one by cutting down their marketing costs and offers economic prices. According to their finding, India is about to face a e-Shopping revolution as it has huge youth population aged between 18 and 40 .

- In an article published by metrics.com, it emphasis on the increase in online revenue. As per their survey, online revenue is enhancing $8.6 \%$ per year. Since soup to nut is available in e-Shopping sites.

- $\quad(2003)^{9} \mathrm{Know}$ and Lee explain about the key reasons for the increase in online shopping. They are ease of shopping comparison, low prices, timely delivery, convenience, time savings, low shipping costs, improved customer service, tax exempt status and speedy e-mail response. Non-adopters are concerned with the payment security and online shopping attitudes.

- $\quad(2003)^{10}$ Karayanni, in her article titled web shoppers and non-shoppers compatibility, relative advantages and demographics stated the marketability of online shopping. She observed that consumer focus on the avoidance of quos and time efficiency.

\section{RELEVANCE OF THE STUDY}

The sharp increase of internet usage as well as systematic progress of information technology and e-commerce has transformed the way goods are bought and sold. Presently, modern customers have become quite smart and always look for choices prior to make a final decision. Online purchasing experienced lot of difference due to various consumers' attitudes and category of products and services provided. In coming years, great online revolution is expected in India, since there is huge population aged between 18 and 40 in the country. Present scenario, thus draws the relevance for the study on peoples' perception towards online shopping.

\section{Methodology}

In this project mainly primary data is used. Data are collected using convenience random sampling method. Both the e-shoppers and non e-shoppers are included in the study with the sample size of 50 each. Responses are gathered by giving separate questionnaire to e-shoppers and non e-shoppers. Further analysis was done with the help of tabulation of data and presented using bar diagram.

\section{OBJeCtIVES OF STUDY}

The present study has been undertaken with the following views:

- To study peoples' perception towards online shopping within selected group of respondents.

- To study in general the merits and demerits of online shopping.

- To give suggestions based on the analyzed results.

\section{LIMITATION OF STUDY}

Limitations which were observed while doing the project are as follows:

- The sample size which is used in the project is too small due to time constraints. A study with more number of samples and time can give more dependable results.

- The time limit for the research was small to gather information for an in-depth study.

- Interaction with online shopping companies would have given more details which was not possible due to time limit.

- Respondents may give biased information.

- The method of study was based on convenient random sampling. Therefore the reliability and accuracy of analyzed results are to be further studied.

\section{ADVANTAGES AND DisAdVANTAGES OF ONLINE SHOPPING}

\section{Advantages}

Online shopping is gaining popularity due to various reasons. With the advent of online shopping or online storefronts consumers are able to get their desired product just at the click of a mouse. Some of the advantages of online shopping are:

- Incredible amount of convenience: Online retailers accept orders twenty four hours a day while consumers who wish to shop at traditional stores have to be available to visit the store during normal business hours. One of the major advantages of online shopping is that, it enables the consumer to shop at anytime from anywhere. Once you have decided on what you want to buy the payment process is seamless and the orders are delivered at your doorstep which eliminates the need for waiting in the long line or waiting till the shop assistant is ready to help you with your purchases. 
- Better prices: Online shops eliminate the need for intermediaries as a result of which consumers are able to buy products at cheaper rates. Many online shops offer discount coupons and rebates.

- Infinite choice: Online shops provide wide range of choices to its customers. One can get several brands and products from different sellers at one place. It also enables its customers to shop from retailers across the boundaries. Plus, if a consumer doesn't see what he or she wants in an online website, they can simply move on to the next site.

- Comparison shopping when online: Instead of running around several different traditional stores and trying to remember or write down details such as prices and features, the shopper can simply open two or more browsers to easily compare more than one item. It also gives the consumer the ability to compare items which may not be available in his or her location. It also enables the consumers to learn more about similar products which helps them to make the best possible decision.

- Buying and selling old or unused stuffs at low prices: There are many sites such as OLX, Quickr, etc. which enables the people to sell their unused or old things online. Similarly, it also enables the consumers to buy old and unused products at rock bottom prices.

- Easy access to consumer reviews: It is easy to access consumer reviews on almost every product that one can think of in online, which helps in making purchase decisions. It also gives one the opportunity to give their feedback.

- Compulsive shopping can be eliminated: Sometimes due to the pressure of the shopkeepers, one ends up buying things that he or she actually doesn't require. Sometimes consumers also tend to compromise their choices due to lack of availability. Such things doesn't happen in an online shopping.

- Send gifts: Online shopping has made it easier to send gifts to relatives and friends no matter where they stay. There are gift wrapping options available in online store. It enables the online shopper to save a great deal of time.

- Reduces the expense: Online shopping reduces the expense of shopping unlike the conventional shopping as one may tend to spend on things like eating out, travelling, impulsive shopping etc.

\section{Disadvanatges}

Every revolutionary idea comes with a baggage. Online shopping has its own set of disadvantages. Some of the reasons that restrict a person from shopping online are given below:

- Internet does not come free of cost: Most of us have internet scheme these days but those who don't, every time you open a page on an online shopping portal to choose a specific item, you get charged for it.

- Deprives you of tangibility: In case of online shopping the consumer cannot touch and check the quality of the product unlike as in case of offline shopping. So one cannot trust online shopping.

- Fear of credit card information being stolen: The major concern of any online shopper would be fear of credit card information being stolen. Online storefronts must ensure that they have all the trust seals in place, SSL certificates etc. so that consumers trust and confidence can be attained.

- Deceptive pictures: Sometimes pictures shown in the online shopping portals are often deceptive in nature. Therefore one might not receive what one is actually expecting.

- No bargaining: Offline shopping enables consumers to try the product before making the final purchase decision especially in case of clothing. Such trials are not possible in case of online shopping.

- Never ending wait for the product to arrive: Once a consumer places an order online, it will take some time for the product to be delivered. Again the period of delivery differs from one site to another. If shipped from overseas, it can take more than a month to reach its destination.

- $\quad$ Shipping costs: Certain sites do not give exemptions from shipping cost. Shipping cost raise the price of the article and thus the consumer may end up buying products at a rate higher than its market price.

\section{FINDINGS}

Given below are the findings that are obtained from the survey conducted on online shopping:

\section{Findings among Online-Shoppers}

- $\quad 38 \%$ of respondents sometimes uses e-shopping

- 'An easy purchase of various products' is the highest merits stated by $66 \%$ of respondents.

- $66 \%$ of respondent stated that quality of the product cannot be justified in online shopping.

- $\quad 72 \%$ of respondent use Flipkart for online shopping.

- $76 \%$ of respondents purchase clothes or shoes from various sites.

- $94 \%$ of respondents encourage others people to do online shopping.

- $\quad 78 \%$ of respondents continue with traditional shopping along with e-shopping.

- $88 \%$ of respondents satisfied with online shopping experience.

- $44 \%$ of respondents agree that online shoppers will be more in future and $44 \%$ of respondents partially agree with the statement.

\section{Findings among Non-shoppers}

- $46 \%$ of respondents stated that lack of quality justification is the reason preventing them from online shopping.

- $\quad 98 \%$ of respondents are aware of various advantages of online shopping.

- $74 \%$ of respondents are fully aware of the various online shopping sites. 
- $92 \%$ of respondents are aware about the various products available through e-shopping.

- $\quad 80 \%$ of respondents prefer online shopping if they get proper knowledge and awareness.

- $58 \%$ of respondents' eye, physical examination of products before buying is highly rated merit.

- $\quad 42 \%$ of respondents do not have proper awareness and knowledge about online shopping which drag them from e-shopping.

- $46 \%$ of respondents agree that online shoppers will be more in future

\section{SugGESTIONS}

- Online shopping sites should not break the trust of the public by providing faulty goods. If trust element is assured there then online shopping will be preferred more.

- There should be transparency in the net banking facilities.

- Along with net banking facilities, cash on delivery scheme should also be provided, since people are more comfortable in the scheme.

- Online shopping sites should be designed in such a way that they should provide all necessary details regarding the product clearly: including quality of the product, different varieties, mode of payment etc so that no confusion exists.

- Measures should be taken to improve customer services. Customers care centers should be established.

- Provision of negotiation should be provided. It should also provide a venue for customers to share their views and suggestions truly.

- Measure should be taken to improve the quality element of the products shopped online.

- Awareness among people should be increased by bring more interesting advertisement relating to it.

- Assurance of the exact product displayed is to be delivered.

- Provisions for replacing the damaged goods should be provided.

- The deliveries of the goods should not be delayed. Accuracy in the delivery should be assured.

- More number of shopping websites which are product specific should be introduced.

- Online shopping sites should have more product lines so as to showcase a large variety of products.

- The goods will not be directly delivered to people staying in rural areas (far off) areas, so necessary arrangements should be done to overcome this problem.

- Size measurement of clothes, shoes, etc should be made simple and standardized.

- There are many fraud websites that are not authentic. Safety measures are to be taken to control these.

- More sites should emerge, where the consumers will have the opportunity to try various varieties (color, size, model, design etc.) of the same product before purchasing it.

\section{CONCLUSION}

A large number of studies have been conducted by various research scholars nationally to explore the factors that may affect online buying perception and behavior of customers. Majority of online sites target the youth or younger generation of the economy as their customer because of technology friendliness.

This project was an attempt to study people perception towards online shopping. The study was conducted by drawing sample of 100 among both e-shoppers and non-shoppers on an equal basis. Variables were considered and offered to respondents in the form of questionnaire. The collection of data was analyzed and interpreted using different charts and tables.

As result of survey it was able to conclude that majority of people favors to do online shopping, even if they felt some difficulties. People who are non-shoppers are ready to do online shopping in the future if they get proper awareness and knowledge. Majority of the people agree that in near future online shopping will be more on demand than offline shopping. Therefore, online marketing have a wider scope in the coming years. More people prefer cash on delivery than net banking. Greater part of respondents encourages other people to enter into e-shopping. Most of people do not shop online due to fear of quality of goods, afraid to give out their credit card details and also they find conventional methods more enjoyable. The fact that large number of people is getting attracted towards online shopping creates a basis for tremendous prospects for marketers of today and tomorrow. It can be concluded that online shopping will take over as the prime marketing and selling channel in India in near future.

\section{REFERENCES}

\section{Websites}

[1] http://theglobaljournals.com/paripex/file.php

[2] http://tomrobertshaw.net/2014/04/april-2014-ecommerce-survey.doc

[3] http://abhinavjournal.com/journal/index.php

[4] http://www.ibimapublishing.com/journals/CIBIMA/cibima.html

[5] http://files.figshare.com/1619517/BO1161320.pdf

[6] http://www.scribd.com/doc/7698365/changing-attitude-of-indianconsumer-towards-online-shopping-doc

[7] http://www.wwwmetrics.com/shopping

[8] http://www.bma.upatras.gr/staff/karayan/articles/karayanni-3.pdf

\section{Journals}

[9] Yadav Renu," Playing it safe”, Money Today, Pp.74-76, 2015.

[10] K. Know and J. Lee, "Concerns about payment security of internet purchases: a perspective on current on-line shoppers", Clothing and Textiles research journal, Pp.174-184, 2003. 